\title{
Translation and Criticism
}

\section{Frederic Will}

At a conference in Paris, in March, 1967, I heard Polish and French poets and translators discuss the problems of translation. Their immediate theme was three anthologies of recent Polish poetry translated into English, French, and German respectively. But they went, of course, quickly and far out beyond the topic at hand. To their efforts at discussing the problems of translation was added a striking piquancy: that much of the conference's discussion of translation was carried on by means of translation. That situation made the whole event more meaningful than I could quite analyze.

The discussers were thereby put into an unusual position. Some of their analyses were communicated to one another in a medium or form which was an example of the thing they were discussing. The conditions of their act of communication were the most eloquent comment to be made on the contents of their communication. Not only the difficulty of translation was illustrated, by that situation; but also the fact that even in talking about translation we go out beyond our analyses, and forget how difficult it is for us even to discuss the difficulty of understanding one another across language barriers.

It is in various ways worth thinking about what kinds of alleviation translation can be, to the burden of language barriers. We often think it can provide equivalents, in a new language, for what was written in another language. This concept of equivalents or equivalence needs a close look, for it opens the door to a flock of confusions. I have fought with the idea already, but it is well worth returning to here.

'Equivalence' usually means, in the kind of case I am thinking of, 'value in a new language which is like and worth the value of that from which the translation was made, the original.' I have already examined some of the roots-ontological and political-of this conviction: here I simply state it. Sometimes this conviction joins with the belief that translations can deal very freely with their originals, and sometimes with the opposite belief, that translations must be very, as it is called, 'literal.' Either of these views, and a spectrum of possibilities lying between them, can be supported by the kind of equivalence-conviction I describe. These opposed views have in common, in the present case, the conviction that they represent ways of establishing equivalence.

There is an alternative to this definition, or at least another way of looking at it; a view of translation which if not original is at least unorthodox, which is backed up by many contexts, and which has the merit of describing translation's relation to the main landmass of meaningful uses of language. 
Translation deserves, under certain conditions, to be considered an extension of an original work, quite as literally as we sometimes consider literary criticism or literary scholarship an extension of literature itself. I mean by extension something entirely different from translation as variation or imitation (in Robert Lowell's sense), in which great latitude is provided for interpretation. 'Interpretation' is a frightening word. The notion of it returns us to the duller aspects of equivalence, the non-ontological aspects. I mean at this point to consider translation as a continuation of the impulse latent in an original.

From the shelf I pick a book by René Char and read:

Le poète ne s'irrite pas de l'extinction hideuse

de la mort, mais confiant en son toucher particulier transforme toute chose en laines prolongées,

and then, translated on the opposite page:

The poet is not angry at the hideous extinction of death, but confident of his own particular touch, he transforms everything into long wools.

The ineptitude of this translation results from giving in to the most pedestrian sense of equivalence. But what use would even a more creative sense of equivalence have been here? Of what interest could it have been in this case even to imitate (in Lowell's sense) imaginatively? One could hardly have done more than, say, make daringly explicit the maggoty, spindly aspects of physical death. This would have helped, but could perhaps best have been achieved by creative translation out from the center of the French. Like this, for a start:

The shaper of poems (1) is not rawed by (2) the tangible stranglegrasp (3) of death, but turns it (4), trusting his touch, into fingers (5), endurable skeins.

One may head, first, for the dominant sense-experience of the original, which here is tactile. (Not amorphous and indifferent, as the equivalent-version suggests). Then the hints from the original begin to accumulate. One realizes what to do with the 'laines prolongées,' that they can be related to 'toucher.' Hence 'fingers' (5) and 'skeins.' One goes for etymological or cultural resonances (as in $1,2,3$ ) which convey the original's sense of effort and texture. One specifies (4) where the original could afford to be general in its reference: with its 'toute chose' which the equivalent translation simply waters down. In short, even in my rough version of an extension-translation, one may follow up a variety of promptings, in the original, in an attempt to continue its work, not to find an equivalent of it.

Such a program of ad hoc strategies may wander off into anarchy. One can go wild picking up all the hints, and be left in the end with a picnic of linguistic oddities. This would be following a too private course. What I said, concerning the dominant sense-pressure of this passage, may serve as a clue to kinds of 
shaping available here to the translator.

In the present passage the problem is relatively simple, as it is in all poetry or poetic prose which springs from a strorgly internalized sense-experience. The texture of the chief component sense will in the reader make itself promptly clear. Usually, though, no so obviously organizational thread is laid down, as is clear in considering, say, La Divina Commedia, Andromaque, or Les Fleurs du $\mathrm{Mal}$. In those cases one must listen. Feit senses of motion-upward, downward, inward, outward-will in Dante join the moral issues so as to suggest strategies, or recurrent tropes, of linguistic behavior. A lyric poet, like Baudelaire, might need to be approached through puns or sound-patterns, whose suggestibility seemed at first quite random, but on second reading turned out to be crucial clues. (Think of the sense-and-sound play between 'soeur' and 'douceur,' LIII, or between end-rhymes like 'tige' and 'vertige,' XLVII.)

That this sketch of a program is worth considering grows convincing only when one considers, in its light, what it is that work with another language, through translation, can accomplish. As translator, one has first to penetrate another language with his own. This sounds odd, but is true. 'Poète' and 'hideuse' and 'mort' are necessarily addressed, by us, through the English words which have introduced us to those three specific meaning-giving signs. 'Poète' first means, to us, in terms of 'poet.' Secondly it means, to us, through what we may happen subsequently to know of its roots (poietes, 'the maker,' in Greek), its cultural resonances, or its tonal qualities. Third, of course, it means all this through what it gathers and bestows significance from, in its context in its own work.

One job of the translator, especially of the translator of the poetic, is to nourish and foster any or all of these meanings, letting them grow from their original soil out through his words into their natural deployment, or at least into one of their possible unfoldings. Similarly with the whole meaning of the original poem, story, or play. We need to let it flower into our words.

'Our'? It would be too little to say that this view treats translation as a means to extending our own language. I am convinced of at least that. I see many cases in which the language of translation should clash with the norms of the speech and writing system from which it emerges. (Zukofsky's translations of Catullus are a brilliant example of total clash.) This kind of clash can be extremely fruitful to any language, as we know in English from the effects of our greatest translations-Chapman's and Pope's of Homer, the King James Bible, Fitzgerald's Rubaiyat-all of which have moved the boundaries of our language farther out around us, so that we breathe more freely inside it.

I am on the whole, though, thinking of nothing so grand, when I speak of letting the words of the original flower into your words; yet I am thinking of something intimately, densely, and experimentally concerned with language extension. I think of the way one can enter the foreign language, and work out with it into a number of its intentions, especially into its guiding intention. Finally I think of the possibilities of occupying, in this way, some of the no man's land which lies between languages, or some of that tertium quid territory which constitutes the ideal language between the particular languages. This means bringing the foreign language toward one's own language. It involves extending one's 
own language, but doing that through building a bridge back into one's own language from a foreign language one has gone out into. The notion of equivalence offers us the false idea of balance in values in different languages. Although such translations as I've discussed here may never give the sense of completeness, they are incomplete only because they are permanently in a state of creative emergence from what is being translated. What they emerge toward is that single, universal language which each of us bears deep in him, as the theoretical horizon which makes linguistic actuality possible.

From a translation of a realistic novelist which would in any sense be adequate, to a similar kind of translation of René Char, would be a great distance. I am conscious of having allowed for translation in both these senses. I'm also aware that earlier in this essay, where I was trying to establish a context-philosophical and historical-for the free and liberal employment of translation, I was also creating a context which would support a far more conventional view of the activity. A world of public literary matter, to which attention was called there, is no more invitation to Christopher Logue than it would be to a translator of Zola. Each of them could find, in publica materies, justification for his own procedure as translator.

This essay has hinted, so far, at a remarkable kind of possibility for translation, and I should like to let my conclusion circle about that possibility, rather than come to rest on a balanced and equable relativism, of the kind justified by the last two sentences of the preceding paragraph. (Though the point made through that relativism seems to me made to stand.)

There is certainly nothing wrong in certain cases with equivalence-translation of prose, nor is there anything sacrosanct in developing the intentions of the original, whether poetry or prose, a business which in most hands-sometimes, say, in Pound's-leads to fatuously ungrounded results. The latter activity is, however, certainly the more daring and fertile of the two, and if we can at the same time find, in it, plausible hints of methods, we may be learning something valuable about all kinds of translation. It deserves a final try.

The plausible hints lie hidden in the direction of the translator's work; back into the original, then out again in the direction proposed by it. Certainly, because I haven't been that careful at definition, this verbal movement is likely to sound like a very daring 'following the curve of the original,' and in a sense I suppose it is. But in the example from Char, which I consciously kept small and unambitious, less than that was shown going on and what was shown seems to me to have been the necessary minimum, for translation which makes any claims on us. (Particularly claims of accuracy.) What was going on was, on one level, a kind of etymological busywork; as in the movement back into 'poète,' 's'irriter,' or 'extinction.' But that busywork was part of finding out what was in the original, and letting it assume its basic meanings again. In 'laines prolongées,' already, more was done. Also, I think, in the turning of 'transforme' into 'turns it.' From etymologizing on up, at that point, translation means bringing back, into a version of the original, some of its toughness, density, or texture. 
This much, I believe, was being done even in the 'flattest' or 'straightest' instances of prose translation. I know that was one of the motives behind the making of successive versions of the short story Fama. To say a lot in nuce, that is what I was after when in translating that Polish story I changed

Mr. Posag, coming downstairs to the men's room, was the nearest to the monument, which behaved so unusually, and he saw most clearly how Fama moved her hand, raised the horn to her lips, and gave a sharp sound

into

Mr. Posag, who was coming downstairs to the men's room, was the nearest to the monument when it behaved so unusually, and it was he who saw most clearly how Fama moved her hand, raised the horn to her lips, and blew sharply.

It was not all I was after-because I was also concerned with a kind of inner sayability in English-but it was part. I was after a moderate restoration of the original's vital qualities.

Basic restoration, then, may be a suitable formula for the moment, and may help, once more, to remove any sense that translation is inadequate unless it achieves a radical freedom. A quite different sense, I think, should ride in the wake of this formula; the sense of the function of translation as a kind of criticism, or at least as an activity significantly related to criticism.

On the busywork level again, translation of the 'basic' kind is a process of constant choice, and is thus, from the outset, 'critical,' 'judgmental,' in recognized senses of those terms. The decision whether to write 'gave a sharp sound' or 'blew sharply' is a complicated, if not very interesting, case of such basic criticism. The decision involves our notions of the whole context of the phrase-thus of the work involved, and ideally, by extension, of the author's whole oeuvre; all this involves, of course, our ears' sharpness, our linguistic preparation, and our sense of ambience and mood in lived life. On this busywork level, translation involves deciding what effect a work is aiming at; and defending one's decision by showing proof. A lot of what we usually consider practical criticism certainly does no more, and not much differently, than that.

Is translation ever more than that kind of busywork? Translation of any critical worth is not only phrase-by-phrase work modified by an active knowing of the whole text; but it is both of those activities working together. What is hard to analyze is this: that the joining of those two activities, if carried out by the process of restoration of the original's vitality, seems to constitute something like the creative process that went into making the original. Not only is this seeming hard to analyze, but it needs analysis. Surely we don't want to admit that good translations, works of good criticism in that sense, are as creative as the original creations to which they are applied.

We don't, just as we naturally reject the idea that good discursive criticism -from Aristotle to Lukacs to Frye-somehow 'makes itself equal' to a body of 
literature by accounting for it. What marks the original literary work, in all cases, is a density and texture which are unique to it. The translation at best is criticism which renders a kind of account of these factors. But it is not a becoming them, in accounting for them.

As that, translation in its critical function remains a kind of guardian of our concern for significant literature. It gives an account of such literature, and is thus, at its most ambitious, as aspiring as the most aspiring of the discursive works which we usually agree to call criticism. And that is not, at this point, to speak of translation as creation. If the meaning of translation as 'account' is still not yet fully worked out, it is nevertheless clearly distinct from 'creation.'

Where one act in words, translation, begins to transform itself into another, criticism, it is likely that we will be especially able to see what the first, the departing, was. It is a privileged moment.

That moment was invited, in the last paragraphs, by an attempt to probe the difference between translation and criticism, as different kinds of account of original texts.

I suppose we need once more, in order to take this distinction farther, to invoke the insubstantiality of original texts. We need to think again, before discussing accounts fully, about what in such cases we are giving an account of.

Original texts are not icons. They are symbolically coded patterns of movement; intention, argument, and the expression of both, theme. They are neither hard nor soft, but are basically process. I like to think of them as participial, rather than nounlike or verblike. Works of literature, there to translate, have a character, a nature each by each, which is like their substance, their mark of personality; but they can make this substance clear, indeed actual, only by enacting it. That action is their verblike side, needed to reveal the nouns in them. In this sense they, literary originals, are participles. They enact the nouns they are, by becoming verbs. They become verbs by enacting the nouns they are.

I touched these factors in hinting at the problem of translating, in general and at all. I mention them now for a new purpose: to assure us of continuing directly into this last question of how or whether translation differs from criticism. Into this question of the kinds of account provided by the two activities.

There are three main differences between the two activities:

FIRST: the worthwhile translation accounts for its original by being physically plaqué, almost plastered, against it. Talk of this kind is needed, to raid the phenomenon in question. I think this plaquing occurs on either of two planes of encounter; either parailel to the original text, against the motion of which it seems to lie, absorbing and adequating that text's motion at every point; or out beyond that text, taking on the text's course of movement, receiving, as I said initially and repeated in the Char example, the thrust of the text's movement. Neither of these positionings-which are spiritual facts, not metaphors-is completely what happens. In no case does a significant parallel translation not also recoil, with the original's thrust, back into the ambience of its own language; 
nor does the thrust-continuing translation ever not in many ways draw continuous nourishment from the process we call its original. But in every worthwhile translation there is the factor of one of these kinds of physical relationship to the original.

Criticism is different. Whether descriptive (Frye), prescriptive (Leavis), or metaphysical (Barthes, Staiger), criticism has either a much less sensuous relationship to its original, or a much less continuously sensuous one. I think here even of Leavis, a hard example; his criticism, though not without great texture and density of its own, is far less densely related to its object, say to a Lawrence novel, than a good translation of that novel would be. As far as accounting goes, criticism is an abstraction. It is for instance much less able than translation to account for the process which the original not only is, but on which the original depends for everything that deploys and elucidates its own character.

SECOND: follows from the first difference. Critical choices are indeed operative at every level of translating; on the phrase-level, on the level of the whole work. This applies equally to parallel and to arc-continuing kinds of translation. These choices, however, operate strictly within the limits set by the original text; by that process, in language, which is being converted. This is the constriction which the gain in sensuousness costs. It is a great expense.

There is of course a sense in which the prerequisites for adequate translation are unlimited, thus in which we can claim that even the translator's most local choices require whatever experience he has had in his own language, and in other languages; it following that the translation incarnates the whole its maker is, as fully as any original work done.

In a sense, as I say, this is true; the reason why it is also true, that translation is a restricting field of choice, is that translating provides only a very small aperture through which the translator can draw his generally very large linguistic sensibilities. On occasion-perhaps in Chapman, Pope, and Fitzgerald-this very smallness acts as incentive, in the way a prosodic limitation might. And in general, I suppose, it does not act as a deterrent, merely as a sieve. But that is enough. Translation is quite especially a choosing-against-the-background-of-prearranged-syntax, and thus a choosing in terms of rather presuggested possibilities, within the translator's own language.

Criticism, of any of the varieties I have mentioned, is more distant than translation from the process which is its object. (What kinds of account, in fact, could be as close-fitting as translation?) At the same time criticism is much freer in its references and implications, freer than translation to deflect these out away from the text it is considering, or to draw them in from other texts. It is also free, of course, to select as radically as it can, in finding the details it wants to examine, and remaining only with them. It is no requirement of criticism, in any of its forms, that it should account for the wholeness of works, or even for the whole of them. By contrast with this, the account given by the translator seems free chiefly in the freedom of his original decision of which work to treat.

THIRD: the good translation tends toward fusion, in its own process, with the process the original is. If criticism is chiefly a way of trying to say what an 
original is, translation is chiefly a way of saying an original. The active marrow of even the most liberal good translation is on loan. The work of conventional criticism is its own substance and its own motor force. Translation, for this reason, tends to be a meaningless notion apart from its original; while criticism, by the very least defence, has a half-life of its own; or as someone like Frye might imaginably argue, has a kind of ontological priority even to literature, of which it names the Ur-forms.

This is precisely where the difficulty arises, in determining whether translation is a form of criticism, and it is too important a point to see trapped in questions of terminology. Translation is in at least two senses a genuine, informative, enriching account of texts. It can be, as we saw in the case of the Char, restoration of the forces and values of the original. It can be a way of getting inside those values and pushing them out, so to speak, so that they can be seen with fresh words attached to them. And it can be a way of making new sensuousthematic textures which 'account' for, 'give an account of,' the original's textures.

As an 'account,' however, it lacks distancing, freedom of reference, and the power to reify, which are crucial to what we generally consider the acts of presenting the knowable. About these acts there is everything still to say. But as we see them beginning to assume definite boundaries, at the end of the spectrum of species of translation, we have a renewed sense of their usefulness, as definers of what translation both is and cannot be. This is an oblique, but useful, way to talk about what criticism is.

FAyad Jamis is a Cuban poet (born 1930) who lived five years in Paris, and now edits Union, the review of the Cuban writers union. His "Por Esta Libertad" is a test case for the theory offered in my essay. There is little, almost no, latitude for the translator of this poem. Jamis' words are everyday words; but they are not "false friends," do not have meanings, in themselves and verbally considered, which they seem not to have. Yet there is a profound problem involved in translating this poem. The poem is a "revolutionary" poem, in the special sense Cuban history has given to that word. The Cuban meaning of "liberty" shapes the Cuban meaning of "factories," "oppressors," the "sweet entrails of the people." The American translator can do nothing about this problem; he must translate directly and hope for the best. He cannot "criticize" while translating this poem, except in the sense that not criticizing, here, is criticizing.

Fernando Retamar is an established Cuban poet-born in 1930, used to hard work like dishwashing in New York City, but now a member of the revolutionary authority. This poem of his does not present the "revolutionary" problems found in Jamis' poem; it offers 
opportunities for interpretation. Those opportunities are small and delicate: how to catch the part physical, part spiritual tone of ligeramente sobrehumanos; how to approximate the word resonance in comestibles and bebestibles; how to meet the unusually forged expression, the diecisiete rostros de la sonrisa. We have taken few rare steps in the translation. But we have tried to compensate lightly, for some of our problems, by a slightly off-normal timbre in our version. This is often as far as the translator can go toward criticism. But it is a long way.

\section{Frederic Will}

\section{FELICES LOS NORMALES}

Felices los normales, esos seres extraños.

Los que no tuvieron una madre loca, un padre

borracho, un hijo delincuente,

Una casa en ninguna parte, una enfermedad desconocida,

Los que no han sido calcinados por un amor devorante.

Los que vivieron los diecisiete rostros de la sonrisa y un poco más.

Los llenos de zapatos, los arcángeles con sombreros,

Los satisfechos, los gordos, los lindos,

Los rintintín y sus secuaces, los que cómo no, por aquí,

Los que ganan, los que son queridos hasta la empuñadura,

Los flautistas acompañados por ratones,

Los vendedores y sus compradores,

Los caballeros ligeramente sobrehumanos,

Los hombres vestidos de truenos y las mujeres de relámpagos,

los delicados, los sensatos, los finos,

Los amables, los dulces, los comestibles, y los bebestibles.

Felices las aves, el estiércol, las piedras.

Pero que den paso a los que hacen los mundos y los sueños,

Las ilusiones, las sinfonías, las palabras que nos desbaratan

Y nos construyen, los más locos que sus madres, los más borrachos

Que sus padres y más delicuentes que sus hijos

Y más devorados por amores calcinantes.

Que les dejen su sitio en el infierno, y basta.

\section{Fernando Retamar}

